\title{
Effectiveness of Outdoor Physics Activities
}

\author{
Christian Ivan B. Camarce \\ Head Teacher III, Batan National High School \\ E-mail: ivanooze2686@gmail.com \\ DOI: 10.47760/cognizance.2021.v01i11.001
}

\begin{abstract}
This paper presents the utilization of outdoor physics activities in the teaching of selected topics in light and optics in order to promote effective transfer of learning in physics and interacting with the environment which is one of the main subjects of the study. The study also looked into the effect of cooperative learning, active learning, use of higher order thinking skills (HOTS), relevance of learning experiences and development of social skills in physics among fourth year high school students in a secondary school in Bacacay, Albay. The researcher developed outdoor physics activities as an instructional intervention and used a single group pretest- posttest design. Qualitative and quantitative techniques were used in the study. The instruments used in data gathering were the teacher- made questionnaire for the features of the outdoor physics activities in optics and results of the pretest- posttest for conceptual understanding and the guide questions for the journal entries of the students. Validation of data was done through triangulation of students' journal entries, self-rating checklist and experts' observation. Positive result shows in the conceptual understanding, development of scientific skills, enhancement on the attitude and values and improvement on the social skillsof the students. Further, it is recommended that additional outdoor physics activities be developed for the enrichment of the students' conceptual understanding as they see their relevance to real life experiences.
\end{abstract}

Keywords: Outdoor physics activities, transfer of learning, conceptual understanding, active learning, relevance to learning experiences

\section{Introduction}

The goals of science education include the development of conceptual understanding and the proper application of science concepts to the practical life of individuals (Image of Science Education, 1992).These goals are associated with progressive education. Progressive education is focused on creating as many authentic learning experiences as possible for students-the kind that will enable them to produce school work that is meaningful and value to them beyond school(Parker \& Adams, 2013). Understanding rests on productive classroom interaction.

From the progressive education's point of view schools must: 1) tap into students' natural curiosity for exploration and growth; 2) employ pedagogical practices that engage students in rigorous, engaged learning; 3 ) respect students as individuals, as learners, and as contributors; 4) teach those skills most needed for success in the world outside of school; 5) Schools must provide students with practice in active citizenship, compassion, service to others, and respect for self and others; and 6) be democratic, inclusive communities in and of themselves(Parker \& Adams, 2013).This will have a great impact on the development of the curriculum, school and learners.

The progressive education is another milestone in science to expose each learner to a wider view of learning. There are so many approaches in science like investigations, experiments, discoveries and exposure which help to improve the quality of science learning. Teaching science outdoors allows 


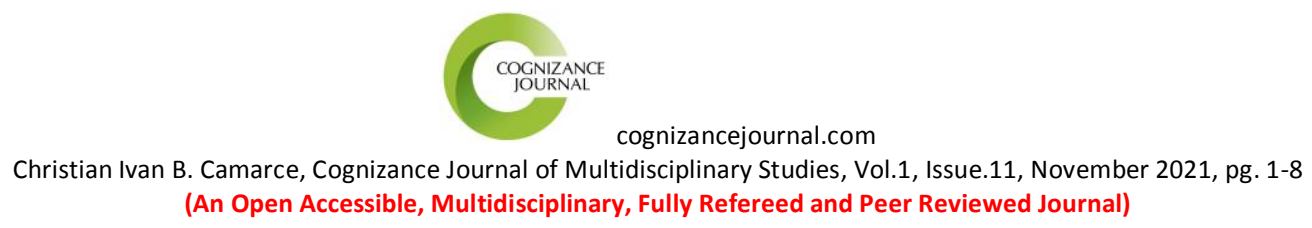

students to investigate the natural world or everyday life. A variety of natural settings can be used for science investigations (Pendrill, 2006). Learning may be done outside the classroom setting.

Discoveries, activities and investigation cannot be achieved easily when a learner stays only inside the classroom. Even scientists naturally discover different laws and theories as they observed phenomena in their natural setting. Sir Isaac Newton, father of classical physics, formulated his Laws of motion based from his observation of an apple that fell from a tree. Likewise, Albert Einstein observed natural phenomena outside the laboratory(Outdoor Science Working Group, 2010).These are examples of discoveries made while observing events as they happen in the natural world. Young students should have the chance to feel the excitement that Newton and Einstein did and this is another challenge to expose the students to the off classroom activities. Many scientists had proven the effect of learning when they are exposed to the natural settings like the playground, garden, ponds and even under a tree. Learning can happen everywhere.

Physics as a science is an art of understanding the rules of nature and their application to daily life. Its laws, principles and theories make it wonderful and exciting to study. The study of physics is an adventure, you will find it challenging, interesting, sometimes frustrating, occasionally painful and often richly rewarding and satisfying(Outdoor Science Working Group,2010). On the other hand, another perception in studying physics is that it is boring, confusing and difficult to study.Therefore there is need to change these perceptions among students by learning concepts in physics in the most authentic ways.

One way to enhance the interest in learning physics is through outdoor activities. In this study, outdoor physics activities were used to make learning enjoyable and more interesting due to the change in the learning environment. This served also as an avenue to develop conceptual understanding of the existing laws, theories and observation.

Physics field experiences can be found both in the natural setting and urban environment.It is better for the students to be aware of the natural phenomena in which physics is involved. Working outdoor gives many possibilities to feel the laws of physics like inertia, state of equilibrium and various optical phenomenon (Popov, 2013).Such experiences enlighten students about the different laws of nature in which physics is applied. This gives them also the opportunity to think about the different laws in physics involved in for example, the falling leaves and moving objects.

One of the concerns of this study is to determine the effectiveness of outdoor physics activities of the fourth year high school students of Bonga National High School while having their discussion on light and optics as their topic in the first grading period. As one of the major areas in science, Physics is given utmost attention since it deals with the physical world and the topics on light and optics are very timely to be introduced as intervention because these topics can best be appreciated outside the classroom. This learning context will enable students to realize the beauty of life and the world. With this, they can also reach a deeper appreciation of the visible world. This is also a very good topic since this is one of the topics that the students find hard to understand.

The study conducted involved introduction of an instructional intervention aimed at developing conceptual understanding among students outside the classroom, promote active learning among students, facilitate learning outcomes, improve their scientific skills such as process and manipulative skills and develop cooperative learning. 


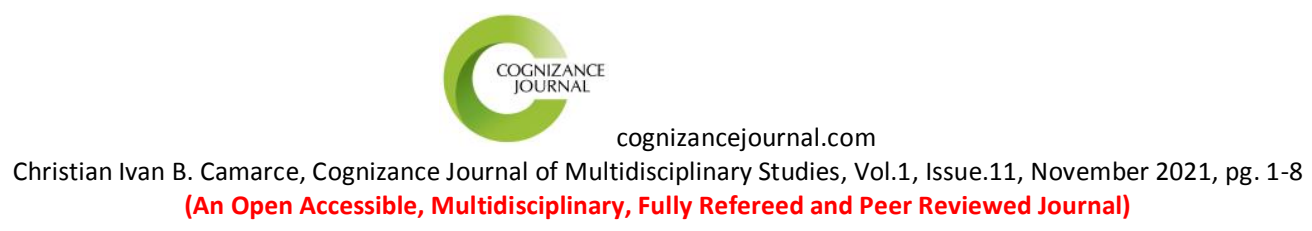

ISSN: 0976-7797

\section{Purpose and Objectives}

The purpose of the study was to determine the effectiveness of the outdoor physics activities The objectives of the study were to: (1) develop outdoor physics activities that will promote transfer of learning, highlighting the following features: (a) conceptual understanding, (b) active learning, (c) relevance of learning experiences, (d) use of Higher Order Thinking Skills (HOTS), and (e) cooperative learning; (2) determine the effectiveness of the outdoor physics activities; and (3) draw from the findings of the study.

By investigating on the effectiveness of outdoor physics activities and the developed outdoor activities, the researcher may lead to relevant findings which will suite the objectives and purpose of the study.

\section{Theoretical Framework}

This study is anchored on the constructivist theory of learning by Jerome Bruner which states that learning is an active process in which learners construct new ideas or concepts based upon their current or past knowledge. He calls his view of learning as "instrumental conceptualism". A learner is a purposive participant in the knowledge getting process who selects, structures, retains and transforms information.

In the learning process, a student uses the knowledge he has acquired and translates this into his own terms in order to solve a problem or to get over a given situation. To him, "learning at its best is thinking". Thinking is the process whereby one makes sense of a hodgepodge of perceived facts through a process called either conceptualization or categorization. He points out further that a learner can use information effectively provided he is able to translate it into his own terms. According to his theory, we construct our own understanding of the world we live in by reflecting on our experiences. Each of us generates our own "rules and mental models" which we use to make sense of our experiences. Learning is a process of adjusting our mental models to accommodate new learning.

One of the guiding principles of constructivism is that learning is a search for meaning. It should therefore start with the issues around which students are actively trying to construct a meaning. These issues can be referred to as the practical situations which students encounter in the learning process. Meaning requires understanding whole as well as parts and parts must be understood in the context of the wholes.

The Cognitive structure (i.e., schema, mental models) provides meaning and organization to experiences and allows the individual to "go beyond the information given". This theory encourages science teachers to let their students engage in some practical work because they can learn better if they perform activities on hand with the use of their abilities (Bruner, 2008).Through this student will not just develop concepts rather it will also lead them to develop psychomotor or manipulative and affective skills.

Still in support of this theory, this study was based on Jean Piaget's cognitive development theory, which focused on how an individual acquires learning while adopting to his/her environment. Piaget gives emphasis that the learners must individually discover and transform complex information if they are to make it their own. Piaget viewed that all individuals pass through the same four stages in their cognitive development in the same order, the sensory motor stage, pre-operational stage, concrete operation stage and the formal operation stage. 


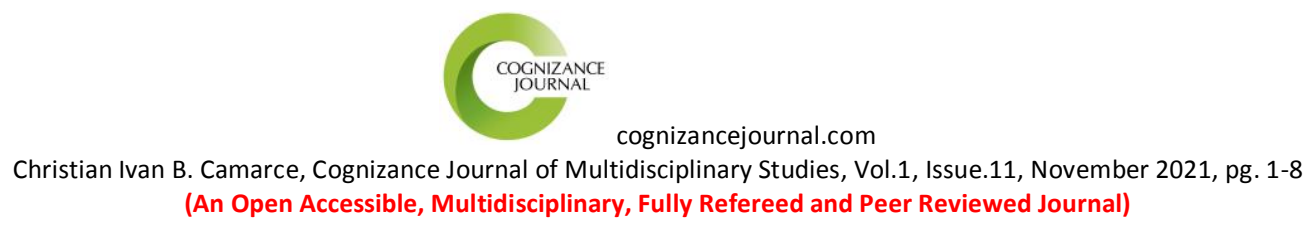

ISSN: 0976-7797

Another theory that influenced the conduct of the study is the theory of connectionism by Edward L. Thorndike. The main thought of the theory is through conditioning, specific response patterns come to be connected with specific stimuli. In line with this theory is the identical elements of theory of transfer which means that learning is facilitated in a new situation to the extent that it contains identical factors or elements that occurred in the earlier learning situations (Bigge\&Shermis, 2004).This served as basis in teaching to promote transfer of learning through meaningful activities such as outdoor physics activities.

The above mentioned theory together with the other theories served as link in transmitting information/ learning to meaningful outcome not just acquisition but rather applying what they've learned in real life situations.

\section{Methods and Procedures}

The researcher developed outdoor physics activities as an instructional intervention and used a single group pretest- posttest design. Qualitative and quantitative techniques were used in the study. The data were obtained from observations and interview conducted during the implementation of the outdoor physics activities as well as the students' answers to the pretest and posttest. The instruments used in data gathering were the teacher- made questionnaire for the features of the outdoor physics activities in optics and results of the pretest- posttest for conceptual understanding and the guide questions for the journal entries of the students. These instruments were validated and checked by panel of experts and pretested before they were used to gather data. Validation of data was done through triangulation of students' journal entries, self-rating checklist and experts' observation.

\section{Result and Discussion}

The three outdoor physics activities which promote transfer of learning are the following: Outdoor Physics Activity No. 1- Scientific Explanation Behind Certain Beliefs, Outdoor Physics Activity No. 2- Heat me Up! Solar Heater and Outdoor Physics Activity No. 3- Save Energy! Use a bottle of light. The features of the outdoor physics activities were identified through the presence of conceptual understanding, active learning, relevance to learning experiences, use of Higher Order Thinking Skills (HOTS) and cooperative learning. All of these are the essential features of the outdoor physics activities. These were designed to ensure that transfer of learning occurs. The table below shows the summary of the essential features of the three outdoor physics activities. 
cognizancejournal.com

Christian Ivan B. Camarce, Cognizance Journal of Multidisciplinary Studies, Vol.1, Issue.11, November 2021, pg. 1-8

(An Open Accessible, Multidisciplinary, Fully Refereed and Peer Reviewed Journal)

Table 1: Summary of the Features of the Three Outdoor Physics Activities

\begin{tabular}{|c|c|c|c|c|}
\hline & $\begin{array}{l}\text { Features of the } \\
\text { Outdoor Physics } \\
\text { Activities }\end{array}$ & $\begin{array}{c}\text { Outdoor Physics Activity No. } 1 \\
\text { "Scientific Explanation behind } \\
\text { certain beliefs" }\end{array}$ & $\begin{array}{l}\text { Outdoor Physics Activity } \\
\text { No. } 2 \\
\text { "Heat Me Up! Solar Heater }\end{array}$ & $\begin{array}{c}\text { Outdoor Physics Activity } \\
\text { No. } 3 \\
\text { Save Energy, Use a bottle of } \\
\text { Light" }\end{array}$ \\
\hline a. & $\begin{array}{l}\text { Conceptual } \\
\text { understanding }\end{array}$ & $\begin{array}{l}\text { - Identifying correct concepts } \\
\text { and misconception } \\
\text { Presentation of correct } \\
\text { concepts using other forms like } \\
\text { comic strips, poster and role } \\
\text { play }\end{array}$ & $\begin{array}{l}\text { - Concepts on reflection of } \\
\text { light are used in } \\
\text { constructing the device “ } \\
\text { solar heater" } \\
\text { Correct ideas are } \\
\text { discussed during the } \\
\text { group presentation } \\
\text { together with its } \\
\text { effectiveness }\end{array}$ & $\begin{array}{l}\text { - Ideas learned from the } \\
\text { discussion can be further } \\
\text { enhanced through the } \\
\text { investigation on the } \\
\text { bottle of light. New } \\
\text { concepts were also } \\
\text { learned. } \\
\text { Presentation of concepts } \\
\text { in a new form or power } \\
\text { point or manila paper } \\
\text { presentation can be done. }\end{array}$ \\
\hline b. & Active learning & $\begin{array}{l}\text { - } \quad \text { Actual conduct of the survey. } \\
\text { Interviews by students during } \\
\text { the data gathering. }\end{array}$ & $\begin{array}{l}\text { - Students performed the } \\
\text { task in constructing the } \\
\text { device. } \\
\text { Different tasks are given } \\
\text { to each member such as } \\
\text { the presenter and the one } \\
\text { in charge of } \\
\text { documentation }\end{array}$ & $\begin{array}{l}\text { - Students involve } \\
\text { themselves in the } \\
\text { improvisation and testing } \\
\text { of device. } \\
\text { Through proper } \\
\text { investigation, students } \\
\text { perform the task and } \\
\text { discover new learning. }\end{array}$ \\
\hline c. & $\begin{array}{l}\text { Relevance of } \\
\text { learning } \\
\text { experiences }\end{array}$ & $\begin{array}{l}\text { - Asking questions that are } \\
\text { related to real life observation. } \\
\text { Recognizing the connection } \\
\text { b/w science and real life } \\
\text { experiences though interview } \\
\text { and checking the real } \\
\text { information. }\end{array}$ & 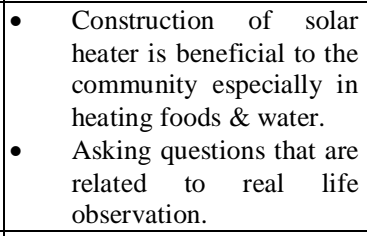 & $\begin{array}{l}\text { - The bottle of light is } \\
\text { beneficial to the } \\
\text { community especially to } \\
\text { the household. } \\
\text { The activity can further } \\
\text { promote conservation of } \\
\text { energy }\end{array}$ \\
\hline d. & $\begin{array}{l}\text { Use of Higher } \\
\text { Order Thinking } \\
\text { Skills (HOTS) }\end{array}$ & $\begin{array}{l}\text { - Critical thinking will be used } \\
\text { in evaluating responses as } \\
\text { either correct or } \\
\text { misconceptions. } \\
\text { Creative way of presenting the } \\
\text { outcome of the inquiry. }\end{array}$ & $\begin{array}{l}\text { - Planning and designing } \\
\text { the device before testing. } \\
\text { Problem solving skills. }\end{array}$ & $\begin{array}{l}\text { - Skills in designing an } \\
\text { investigation. } \\
\text { Use of controlling } \\
\text { variables in designing } \\
\text { activities to address real } \\
\text { life concerns. }\end{array}$ \\
\hline & $\begin{array}{l}\text { Cooperative } \\
\text { learning }\end{array}$ & $\begin{array}{l}\text { - Group gathering of data. } \\
\text { - Group presentation of outputs }\end{array}$ & $\begin{array}{l}\text { - Group planning and } \\
\text { construction of the } \\
\text { device. } \\
\text { Group preparation and } \\
\text { presentation of output }\end{array}$ & $\begin{array}{l}\text { Group cooperation in } \\
\text { designing the device and } \\
\text { installation of the device. } \\
\text { Each member was given } \\
\text { specific role and } \\
\text { responsibility while } \\
\text { working collaboratively } \\
\text { towards a common goal. }\end{array}$ \\
\hline
\end{tabular}

Based from the jurors analysis of the outdoor physics activities all their features were found to have resulted in positive outcomes. The features such as the use of active learning, cooperative learning and their relevance to learning experiences were found to be "very highly evident" on the three outdoor physics activities with equal mean scores of 4.60 while "highly evident" on the features of conceptual understanding and use of higher order thinking skills with means of 4.44 and 4.38 , respectively. This was illustrated on the table below. 
cognizancejournal.com

Christian Ivan B. Camarce, Cognizance Journal of Multidisciplinary Studies, Vol.1, Issue.11, November 2021, pg. 1-8

(An Open Accessible, Multidisciplinary, Fully Refereed and Peer Reviewed Journal)

ISSN: 0976-7797

Table 2: Summary of Jurors' Assessment of the Features of Outdoor Physics Activities

\begin{tabular}{|c|c|c|c|c|c|}
\hline \multirow[b]{2}{*}{ Features of the Outdoor Physics Activities } & \multicolumn{3}{|c|}{ Outdoor Physics Activities } & \multirow{2}{*}{ Average } & \multirow[b]{2}{*}{ Description } \\
\hline & $\begin{array}{c}\text { Activity } \\
\text { No. } 1\end{array}$ & $\begin{array}{c}\text { Activity } \\
\text { No. } 2\end{array}$ & $\begin{array}{c}\text { Activity } \\
\text { No. } 3\end{array}$ & & \\
\hline A. Conceptual Understanding & 4.40 & 4.47 & 4.47 & 4.44 & Highly evident \\
\hline B. Active Learning & 4.53 & 4.60 & 4.67 & 4.60 & $\begin{array}{c}\text { Very highly } \\
\text { evident }\end{array}$ \\
\hline C. Relevance to Learning Experiences & 4.40 & 4.60 & 4.67 & 4.56 & $\begin{array}{c}\text { Very highly } \\
\text { evident }\end{array}$ \\
\hline D. Use of Higher Order Thinking Skills (HOTS) & 4.33 & 4.40 & 4.47 & 4.38 & Highly evident \\
\hline E. Cooperative Learning & 4.60 & 4.60 & 4.60 & 4.60 & $\begin{array}{c}\text { Very highly } \\
\text { evident }\end{array}$ \\
\hline Average Weighted Mean & 4.45 & 4.53 & 4.58 & 4.52 & $\begin{array}{c}\text { Very highly } \\
\text { evident }\end{array}$ \\
\hline
\end{tabular}

Of the three outdoor physics activities, Outdoor Physics Activity No. 3 "Save Energy, Use a Bottle of Light" got the highest mean in terms of presence of all the features, followed by Outdoor Physics Activity No. 2 "Heat me Up, Solar Heater"; and Outdoor Physics Activity No. 1 "Scientific Explanation behind certain Beliefs," last. The three outdoor physics activities helped increase the conceptual understanding of the students as observed in the pre-post test results of the students conducted by the researcher. On the scientific skills, both process and manipulative skills were "highly observed" in the study since they showed positive results on the three outdoor physics activities. These skills got an overall mean of 4.12 interpreted "much observed", a rating supported by the students' journal entries.

Cooperative learning was also "highly observed" in the study which was supported by the different reflections made by the students in their journal entries. Majority of the groups worked together and spent their time doing the activities. The dynamic involvement of the students in the learning process was manifested in the design of the outdoor physics activities. Majority of the students developed conceptual understanding having realized a mean gain of 4.52 in the topics nature of light, dispersion and color formation, reflection of light, refraction of light and total internal reflection. The students also acquired scientific skills such as process skills and manipulative skills. Active learning was also enhanced since students showed more participation in the learning tasks and they were observed to have been responsible and in control of their own learning. It was recommended that the developed outdoor physics activities be used by science teachers in teaching light and optics in high school, to expose students to outdoor physics experiences, and increase their retention of learning. Teacher should expose their students to the different outdoor physics activities not just on the topic light and optics but also on other major components such as electricity and mechanics. This will help them to learn in the natural setting as they use the different resources found in the environment.

Data showed that values and attitude towards outdoor physics activities had positive result having a mean of 4.12. Students agreed that performing the tasks outside the classroom gave them the opportunity to work independently and to observe proper attitude towards work. The outdoor physics 
cognizancejournal.com

Christian Ivan B. Camarce, Cognizance Journal of Multidisciplinary Studies, Vol.1, Issue.11, November 2021, pg. 1-8

(An Open Accessible, Multidisciplinary, Fully Refereed and Peer Reviewed Journal)

activities developed the higher order thinking skills among the students. The expert-observers assessed the higher order thinking skills as "highly evident," based on the following indicators: The activities provided required the use of higher order thinking skills like critical thinking, creative thinking, problem solving, and/or decision making skills (4.2); It promoted the application of science process skills learned in the classroom to a real life investigation (4.53); It provided opportunity for developing students' skills in designing activities and/or devices to address a real life concern (4.40).

\section{Conclusion}

This study sought to answer the effectiveness of the outdoor physics activities in the lesson physics. Therefore the following conclusions were deduced: 1. In this study three outdoor physics activities have been developed intended to promote effective transfer of learning which were indicated by conceptual understanding, active learning, cooperative learning and development of Higher Order Thinking Skills (HOTS); 2. The features of the outdoor physics activities developed are found to be very highly evident; 3 . The outdoor physics activities improved the student's conceptual understanding, scientific skills, attitudes and values and social skills.

\section{Recommendations}

Outdoor physics activities are recommended to be used in teaching to develop in the students scientific skills such as process and manipulative skills, and appreciation of the subject as they apply these skills in daily life situations. Further, it is recommended that additional outdoor physics activities be developed for the enrichment of the students' conceptual understanding as they see their relevance to real life experiences. The school administrators are enjoined to support the use of outdoor physics activities in science teaching through designing educational activities and programs which can be used to improve the quality of classroom settings and enhance transfer of learning. Curriculum should likewise be enriched to consider the use of the outdoor physics activities in teaching Physics and use this in other learning areas as well. Lastly, future researchers are encouraged to conduct other outdoor physics activities in teaching Physics and explore other determinants of effectiveness.

\section{Acknowledgement}

The researcher acknowledges Dr. Lorna M Miña for the guidance and mentorship on the development of the original master's thesis from which this study was obtained. Appreciation is also given to the members of the panel, Dr. Marcia Corazon P Rico, Prof. Gerard M Protacio, Prof. Flor A. Jenkin and Dr. Sheila I. Arroco for the inputs in the original thesis. The researcher is also fully indebted to Provincial Education Division (PED), for the scholarship assistance (GRASSP) of the original thesis. Sincere gratitude is also expressed to Mr. Heminigildo B Camarce, Mr. Gerald Balmaceda, Ms. Merry France Balilo, Ms. Arianne Rose B Camarce, Mr. Michael Bibon and Ms. Rosa Batalla-Camarce who made significant contributions in the success and publication of the paper.

\section{The Author}

Christian Ivan B. Camarce is a graduate of Doctor of Philosophy in Educational Foundations $(\mathrm{PhD}$ EF) at Bicol University Graduate School, Legazpi City, Philippines. It is in this same university where he earned his Master of Arts in Physics Education (MA PhyEd) degree. To date, he is serving as a School Head at Batan National High School, Batan, Rapu-Rapu, Albay, Philippines and as a researcher. 
cognizancejournal.com

Christian Ivan B. Camarce, Cognizance Journal of Multidisciplinary Studies, Vol.1, Issue.11, November 2021, pg. 1-8

(An Open Accessible, Multidisciplinary, Fully Refereed and Peer Reviewed Journal)

ISSN: 0976-7797

\section{References}

[1]. Bigge, Morris L. \&Shermis, Samuel S. (2004).Learning Theories for Teachers, $6^{\text {th }}$ edition. Boston: Pearson, p. 211

[2]. Bruner, Jerome. (1961). “The Act of Discovery” Harvard Educational Review 31 (1): pp. 21 - 31.

[3]. Bruner, Jerome. Constructivist Theory available at: http://tip.psychology.org/bruner.html. Retrieved on May 2013

[4]. Cordovilla, Jo- Anne M., et. al,(2000). The collection of Physics Handouts for Practical Works, $2^{\text {nd }}$ edition., p. 150.

[5]. Deuna, Melecio C, as cited by Halen R. Monreal.(1989)."Project 2061: Report on Literacy Goals of Science, Mathematics and Technology." De La Salle University

[6]. Edmondson, K.M. \& Novak, J.D. (1993). "The Interplay of Scientific Epistemological Views, Learning Strategies and Attitude of College Students.” Journal Research in Science Teaching vol. 30, pp. 547-559.

[7]. Edwards, A. (199). Researching pedagogy: a Socio cultural agenda. In D. Scott (ed.), Curriculum studies: major themes in education. Pedagogy, RoutledgeFalmer, London \& NY,v. 3, pp. 7-31

[8]. Foster, S. (1989). Streetwise Physics. School Science Review, vol. 70 no. 254,pp. 15-17. Image of Science Education. (1992).Deaken University, Geelong Victoria, Australia: Deaken University Printey.

[9]. Outdoor Science Working Group (OSWG). (2013). Outdoor Science, report p. 2. www.nuffiledfoundation.org.

[10].Parker, F.W. and Addams, J. (2013). Defining Progressive Education, available at: http://www.ers.org/ERSBulletins/0399f.html.

[11].Pendrill, A.M. (2006). Learning Physics with the body. In R. Janiuk and E.Samonek

[12]. Miciuk(eds.), Science and Technology Education of a Diverse World: dilemmas, needs and partnerships. Marie CurieSklodowska University Press. Lublin. The Journal on Elementary Education.Vol.31 no. 2, pp. $21-27$

[13].Popov, Oleg. (2013).Developing Outdoor Physics Projects using the Activity Theory Framework. Project Report available at www.nshu.se/download/3935/020g04popov slutrapportfinalversion.pdf 